\title{
RETAIL BANK ATM'S SERVICE QUALITY AFFECTING CUSTOMER SATISFACTION: AN ATTEMPT TO DRAW THE ATTENTION
}

\author{
Dr. P. Balthandayutham ${ }^{*}{ }^{\square}$, Dr. R. Sritharan ${ }^{2}$ \\ ${ }^{* 1}$ Assistant Professor, Department of Business Administration, Government Arts and Science \\ College Valparai, Tamil Nadu \\ ${ }^{2}$ Associate Professor, Business Administration, Annamalai Univeristy, Tamil Nadu
}

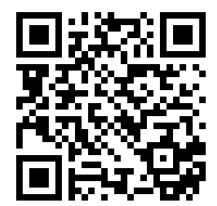

DOI: https://doi.org/10.29121/ijetmr.v7.i7.2020.739

Article Citation: Dr. P.

Balthandayutham, and Dr. R.

Sritharan. (2020). RETAIL BANK

ATM'S SERVICE QUALITY

AFFECTING CUSTOMER

SATISFACTION: AN ATTEMPT TO

DRAW THE ATTENTION.

International Journal of Engineering

Technologies and Management

Research, 7(7), 97-101.

https://doi.org/10.29121/ijetmr.v7

i7 2020.739

Published Date: 31 July 2020

Keywords:

Customer Satisfaction

Service Quality

Atm Service Quality

Retail Bank

Service Quality Gap

Paired Sample T-Test

\begin{abstract}
The study presented here is an attempt to draw the attention of bankers towards the factors that has an influence over the satisfaction of customers regarding the ATM services provided to them. The study made use of primary data which was collected through a questionnaire. The sample size of the study was 100 and the respondents were selected randomly from Chennai. Findings of the analysis show that most of the service quality have positive gap only eight service quality attributes have high expectation in retail bank service but the perception of service quality is very less. Hence it is concluded from the study that only eight attributes exhibit negative gab.
\end{abstract}

\section{INTRODUCTION}

The individuals get the facility of finance from retail banks. The main functions of retail banks are money management, credit and deposit. Retail banking is one of the major innovations of commercial banks. It is the concept through which the banks have direct dealings with the customers than through the corporate or any other banks. The main and core function of retail banking is offering credit to customers (Vidhya, K., Rajakumar, C, S.,2014, $2015,2016)$. These banks offer credit to all types of concerns starting from small unite to large business and the amount also varies from small value to big. This banking also comprises of attracting deposits and products which are asset linked (Vethirajan. C 2016, 2017, 2018a, 2018b.2018c,2018d; Ramu, C., Vethirajan, C, 2019; Madavan, K., \& Vethirajan, 2019 Madavan, K., \& Vethirajan 2020).

The banking industry can grow in a fast pace with the help of technology. The technology of information and communication is the major innovation in technological field which has empowered the access, storage, process and dissemination of data electronically. One such facility offered to the customers by the banks id the provision of ATM service. The customers can avail of 24 hours cash delivery and account balance checking through ATMs.

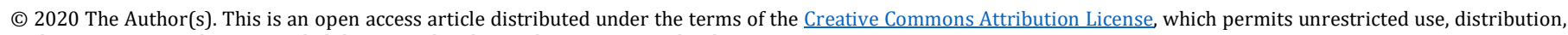
and reproduction in any medium, provided the original author and source are credited. 
Retail Bank Atm's Service Quality Affecting Customer Satisfaction: An Attempt to Draw the Attention

Service quality (SQ) is a comparison between perceived expectations (E) and perceived performance (P) of a service, the equation for finding the service quality gap is SQ=P-E (P Balathandayutham, R Sritharan, 2013, 2014; Rajakumar, C, S., Anandanatarajan, K.,2008,2019)

\subsection{STATEMENT OF THE PROBLEM}

As far as the ATM usage is concerned, several issues are faced by the customers while using it. Those issues include; lack of sufficient money n machines, charging money even when money is not apportioned, and card gets struck in the machines and so on.

\subsection{NEED FOR THE STUDY}

It has become necessary to examine the satisfaction level of customers regarding the various services offered by the ATMs to improve the service quality.

\subsection{OBJECTIVE OF THE STUDY}

The purpose of this paper was to investigate the ATM service quality gap.

\section{REVIEW OF LITERATURE}

Ranasinghe Arachchige et al., (2017) had investigated the effect of service quality of ATMs on the satisfaction of customers in Sri Lanka. Questionnaire was used to collect the primary data for the study. Data was collected from 30 banks. For checking the validity and reliability of the assessment items, factor analysis was employed in the study. The sample size of the study was 385. For exploring the factors affecting satisfaction, regression, t-test and ANOVA were performed. The satisfaction of customers was explored by frequency analysis. It was found from the study that there was a positive relation between customer satisfaction and the ATM service. Also the age and education of customer was found to moderate this relationship.

Adewusi, Aderogba (2012) the purpose of this study was to investigate the service level of Nigerian banks through their ATMs and also how they are perceived by their customers. Even though the banks of Nigeria had initially provided best services at ATMs, it had gradually started to decline over years to satisfy the customers at the ATM centres. a lot of complaints had been observed like lack of solving grievances at the machines, improper management of cards, ATMs with fault, network failure and so on. The authors had tried to focus on the duties of the banks to resolve the customer's problems to gain their continued patronage.

Yavas, Ugur \& Bilgin Wührer, Zeynep \& Shemwell, Donald. (1997). have conducted as study on Service quality in the banking service. Primary data was collected and analysis was carried out. The results reveals that relationships between service quality and customer satisfaction have positive relationship, complaint behaviour and commitment have significant relationship exist. Concludes that the effective service quality of bank has reflects that retention of satisfied customers. This study shows that less expectation and high perception gives positive gap.

\section{RESEARCH METHODOLOGY}

Primary data was used in the study which was collected through a questionnaire. The sample population consisted of 100 respondents from the private banks of Chennai. The respondents were selected randomly. The collected data was analyzed with the help of paired sample t-test. Service quality instrument was adopted from Parasuraman et al (1981) 


\section{ANALYSIS AND INTERPRETATION}

Paired sample t-test.

\begin{tabular}{|c|l|c|c|c|c|c|}
\hline Sl & Service Quality Attributes & Perc & Exp & Gap & t-test value & $p$-val \\
\hline 1 & Update equipment & 3.97 & 3.37 & 0.60 & -5.016 & 0.000 \\
\hline 2 & Visually appealing & 3.62 & 3.52 & 0.10 & -0.866 & 0.388 \\
\hline 3 & Neat dressed & 3.50 & 3.22 & 0.29 & -2.762 & 0.007 \\
\hline 4 & Good appearance & 3.84 & 3.62 & 0.23 & -2.235 & 0.027 \\
\hline 5 & Service as promised & 4.06 & 3.77 & 0.29 & -2.178 & 0.031 \\
\hline 6 & Bank employee is kind and supportive & 3.71 & 3.64 & 0.07 & -0.675 & 0.501 \\
\hline 7 & Bank employee is dependable & 3.74 & 3.57 & 0.17 & -1.588 & 0.115 \\
\hline 8 & Promised time & 3.99 & 2.21 & 1.78 & -11.454 & 0.000 \\
\hline 9 & Records accurately & 4.10 & 3.87 & 0.23 & -1.858 & 0.066 \\
\hline 10 & Bank employee inform customers & 3.28 & 2.17 & 1.11 & -8.562 & 0.000 \\
\hline 11 & Do not provide prompt service & 3.10 & 2.32 & 0.78 & -5.695 & 0.000 \\
\hline 12 & Always to help customers & 3.01 & 2.45 & 0.56 & -4.718 & 0.000 \\
\hline 13 & Too ready to respond to customers & 2.98 & 2.64 & 0.34 & -3.308 & 0.001 \\
\hline 14 & Trust employees of the bank & 3.67 & 3.57 & 0.10 & -0.791 & 0.431 \\
\hline 15 & Feel safe in their transactions & 3.58 & 3.75 & -0.17 & 1.673 & 0.097 \\
\hline 16 & Employees are always polite & 3.50 & 3.66 & -0.16 & 1.429 & 0.156 \\
\hline 17 & Adequate help from their employer & 3.68 & 3.74 & -0.06 & 0.601 & 0.549 \\
\hline 18 & Give individual attention & 2.98 & 2.29 & 0.70 & -5.518 & 0.000 \\
\hline 19 & Give personal attention to their customers & 3.00 & 2.33 & 0.67 & -5.061 & 0.000 \\
\hline 20 & Aware of the needs of the customers & 3.52 & 2.56 & 0.97 & -5.154 & 0.000 \\
\hline 21 & Employees do extend true hearted customers & 3.43 & 2.31 & 1.12 & -6.372 & 0.000 \\
\hline 22 & Office hours convenient for the customers & 3.28 & 2.48 & 0.80 & -5.250 & 0.000 \\
\hline
\end{tabular}

The response options were anchored on a five-point scale for each item of retail bank service. The mean score of each service quality factor was calculated in order to point out a measure of importance of each item as shown in Table. It was experiential that the mean perception rating was higher than the mean expected rating which yields a positive gap for all corresponding service quality attributes. These outcomes were expected because of high satisfaction in many service quality of retail bank. Such findings indicated that there were many factors that influence the satisfaction. The biggest gap of a value 1.78 was for service quality attribute 8 . While the smallest gap of a value 0.07 was for service quality attribute 6 .

Eight service quality attributes have high expectation in retail bank service but the perception of service quality is very less. Hence it is concluded from the study that only eight attributes exhibit negative gab.

\section{CONCLUSION}

The purpose of the study is to explore the dimensions of service quality of ATMs which contribute towards the satisfaction of customers. Suggestions are also given like sufficient cash balance in machines and quick redress of grievances by banks so as to assure the satisfaction of customers. The study assesses the aspects of ATM service by making an understanding of the perceptions of customers towards the service quality. Eight service quality attributes have high expectation in retail bank service but the perception of service quality is very less. Hence it is concluded from the study that only eight attributes exhibit negative gab.

\section{SOURCES OF FUNDING}

None. 
Retail Bank Atm's Service Quality Affecting Customer Satisfaction: An Attempt to Draw the Attention

\section{CONFLICT OF INTEREST}

None.

\section{ACKNOWLEDGMENT}

None.

\section{REFERENCES}

[1] Adewusi, Aderogba. (2012). Customers' Perception of ATM Service Quality in Ibadan. 10.13140/2.1.1981.9847.

[2] Anandanatarajan, K., "Antecedent and consequences of service quality in hotel industry - A guest perspective", in Dholy Grace Management Review 4 (1), 87 - 94, 2012.

[3] Balathandayutham, P., Sritharan, R., "Service quality survey in apartment industry: a study on residential satisfaction among urban resident", IISRO Multi-conferences proceeding, 2013

[4] Balathandayutham, P., Sritharan, R., "A study on the influence of service quality on Apartment Satisfaction in Chennai, Tamilandu", Bonfring International Journal of Industrial Engineering and Management, 2014

[5] Balathandayutham, P., "A Study on the Satisfaction of the Elderly People in Apartment Culture", in International Journal of Management Studies, Vol.-V, Issue -1(3), 145-150, 2018

[6] Madavan, K., \& Vethirajan, C., (2020) "Customer Satisfaction on E-Banking Services of Public and Private Sector Banks in Puducherry Region -An Empirical Analysis". 11. 649-664. 10.34218/IJM.11.6.2020.054, 2020.

[7] Madavan, K., \& Vethirajan, C., (2020) “The Impact Of Electronic Banking Services On The Public And Private Sector Banks In Puducherry Region”. Aegaeum. 8. 1046-1056, 2020.

[8] Madavan, K., \& Vethirajan, C., (2019) "Analysis of customer satisfaction and post-usage behaviour towards ATM services of private sector banks in Puducherry region". 2019.

[9] Rajakumar, C, S., Anandanatarajan, K., "Guest perception on service quality a study with reference to hotel industry", in journal of Asian business management 1 (1), 139-146, 2009.

[10] Rajakumar, C, S., Anandanatarajan,. K., "Satisfaction and Image as the predictors of customer loyalty - An Empirical study in hotel industry", In Annamalai University Humanities Journal 45, 341 - 354, 2008.

[11] Ranasinghe Arachchige, SudathWeerasiri Kosala, ChulaniKoththagoda (2017), The Impact of Automated Teller Machines (ATMS) Service on Customer Satisfaction: A Study Based On State Banks in Sri Lanka, SAARJ Journal on Banking \& Insurance Research, Vol 6 No 2, March 2017, PP 1-11

[12] Vidhya, K., Rajakumar, C, S., "An empirical study on perceived service quality and patient satisfaction with special reference to Puducherry hospitals", in Asia Pacific Journal of Research 2014, vol: 1 issue xiv

[13] Vidhya, K., Rajakumar, C, S., "Emotional attachment and its impact on perceived service quality and patient satisfaction in Puducherry hospitals", in Asia Pacific Journal of Research, vol: 1. issue xxxi, 2015

[14] Vidhya, K.. Rajakumar, C, S., Jyothi, K, T., "An Empirical Study on Patient Delight and the Impact of Human and non-Human Factor of service quality on Patient satisfaction in Private Hospitals", in Journal of Business and Management, 20-27, 2013.

[15] Vethirajan, C., "Impact of Supply Chain Management - Service Quality Strategies for Gaining Competitive Advantage”, In NXT GEX Logistics Management 4.0 Pg- 76-81. ISBN No: 978-0-6482502-1-0, 2018.

[16] Vethirajan, C., "Modern Banking Services in India - A key tool for Indian Banking Sectors". In DBJC - Journal of Business Research, Jain Spire. National Business Research Conference on "Emerging trends in Commerce and management in the present decade" Pg 366-370 ISSN: 2248-9711, 2018.

[17] Vethirajan, C., "Impact of Supply Chain Management - Service Quality Strategies for Gaining Competitive Advantage”, In NXT GEX Logistics Management 4.0 Pg- 76-81. ISBN No: 978-0-6482502-1-0, 2018.

[18] Vethirajan, C., "Modern Banking Services in India - A key tool for Indian Banking Sectors". In DBJC - Journal of Business Research, Jain Spire. National Business Research Conference on "Emerging trends in Commerce and management in the present decade" Pg 366-370 ISSN: 2248-9711, 2018. 
[19] Vethirajan. C., "Insurance Services and Consumer Protection" National Seminar on Consumer Protection and empowerment in India - In ISBN No: 978-81-928690-1-8, 2016.

[20] Vethirajan. C., "User's Opinion on Efficiency of Internet Financial Reporting Practices - A Study with reference to Karaikudi Town", In Paripex- Indian Journal of Research, Vol: 6, Issue:7, July 2017, PP: 18-20. ISSN: 22501991, UGC Approved journal (Sr.47432), Index Copernicus IC Value: 79.96, Journal DOI: 10.15373/22501991, Impact Factor: 5.761.2017.

[21] Yavas, Ugur \& Bilgin Wührer, Zeynep \& Shemwell, Donald. (1997). Service quality in the banking sector in an emerging economy: A consumer survey. International Journal of Bank Marketing. 15. 217-223. $10.1108 / 02652329710184442$ 